Chronologia (2021) vol. 3 no. 1 hal. 14-25

http://dx.doi.org/ 10.22236/jhe.v3i1.6392

E-ISSN: 2686-0171

\title{
Konsep The new urban history dalam Studi Kasus Perubahan Monumen KNIP ke Monumen Sarinah di Kota Malang
}

\section{The new urban history Concept in a Case Study of the Change of the KNIP Monument to the Sarinah Monument in Malang City}

\author{
Rizka Cahyaning Arifin Putri \\ $\bowtie$ Pascasarjana Pendidikan Sejarah Universitas Negeri Malang \\ E-mail: rizkaarifin@gmail.com ${ }^{凶}$
}

Diterima: 27 Januari 2021 | Direvisi: 29 Juli 2021 | Diterbitkan: 29 Juli 2021

ARTICLE INFO

\section{Keywords:}

History,

Urban,

Monument,

Malang.

\section{Kata Kunci:}

Sejarah,

Kota,

Monumen,

Malang.
ABSTRACT

Writing history or historiography in Indonesia has two periods. Traditional and modern historiography. In modern historiography studies began to appear for discussion. There are studies in modern historiography such as oral history, social history, urban history, rural history, economic history, women's history, cultural history, religious history, political history, thought history, quantitative history and the history of mentality. A number of these areas have not been considered in depth, including one of the city's history. This is because there's an overlap in the history of the city. From this point on, the limits of city history are needed. One of the concepts available in the field of city history is the new urban history. The study involves qualitative methods. Research is done with library studies and interviews. Writing this time would explain the limits of the city's history study along with the concept of the new urban history. The next discussion involved the study of the case of KNIP monument change to Sarinah monument in the Malang city. This discussion of case studies is expected the concept of the new urban history to be clearly understood.

Penulisan sejarah atau historiografi di Indonesia memiliki dua periodisasi. Historiografi tradisional dan historiografi modern. Dalam historiografi modern berbagai bidang kajian mulai muncul untuk dibahas. Ada berbagai bidang kajian dalam historiografi modern seperti sejarah lisan, sejarah sosial, sejarah kota, sejarah pedesaan, sejarah ekonomi, sejarah wanita, sejarah kebudayaan, sejarah agama, sejarah politik, sejarah pemikiran, sejarah kuantitatif dan sejarah mentalitas. Bidang sejarah tersebut ada beberapa yang belum dikaji secara mendalam, termasuk salah satunya sejarah kota. Hal ini dikarenakan ada tumpang tindih dalam pembahasan sejarah kota. Maka dari itu, perlu diperjelas batasan-batasan bidang kajian sejarah kota. salah satu konsep yang ada dalam bidang kajian sejarah kota adalah the new urban history. Penelitian ini menggunakan metode kualitatif. Penelitian dilakukan dengan studi pustaka dan wawancara. Pada penulisan kali ini akan dijelaskan mengenai batasan kajian sejarah kota beserta dengan konsep the new urban history. Pembahasan selanjutnya yaitu terkait dengan studi kasus perubahan Monumen KNIP menjadi Monumen Sarinah di Kota Malang. Pembahasan mengenai studi kasus ini diharapkan konsep the new urban history dapat dipahami secara jelas. 


\section{PENDAHULUAN}

Penulisan sejarah (historiografi) di Indonesia dibagi menjadi dua yakni historiografi tradisional dan historiografi modern. Historiografi tradisional terdapat dipenulisan babad dalam khazanah sastra, sedangkan historiografi modern mulai muncul pada sekitar abad 19-20 (Kuntowijoyo, 2003). Perkembangan historiografi ini juga menandakan adanya perkembangan pola pikir dan pendidikan. Banyak orang-orang yang mulai sadar akan pentingnya menulis.

Pembahasan mengenai sejarah kota masih terkesan jarang dikalangan akademisi. Belum ada perhatian yang lebih untuk membahas sejarah kota. Hal ini mungkin dikarenakan kurangnya kepercayaan dan berbagai kemungkinan dari sejarah kota itu sendiri, padahal sejak abad ke-20 kota-kota sudah banyak berkembang dan mengambil alih peran dari pedesaan (Kuntowijoyo, 2003). Pembahasan mengenai sejarah kota masih terbilang asing terutama dikalangan mahasiswa ketika menyusun tugas akhir, mayoritas masih membahas sejarah lokal yang dapat dikatakan sebagai sejarah pedesaan. Sangat jarang mahasiswa yang membahas tentang sejarah kota bersama moderenitasnya. Pernyataan tersebut juga diperkuat dengan berbagai fakta ketika menelusuri artikel yang berhubungan dengan sejarah di mesin pencarian maka akan ditemukan bahwa sejarah kota lebih banyak termuat dalam portal-portal resmi daerah tersebut, ketimbang di artikel-artikel ilmiah yang publish di jurnal ataupun skripsi yang memiliki akses terbuka.

Terjadi pergeseran peran dari desa ke kota diketahui karena adanya perkembangan sosial dan budaya dalam masyarakat. $\mathrm{Di}$ era kolonialisme perlawanan terhadap penjajahan tidak lagi dilakukan di desa-desa, namun berpusat di kota. Hal ini karena berkembangnya masyarakat yang terpelajar. Budaya-budaya modern yang masuk ke kota juga mempengaruhi adanya pergeseran peran budaya desa yang sebelumnya sudah ada (Kuntowijoyo, 2003). Dapat dilihat bahwa kota sebenarnya sudah memiliki perkembangan tersendiri dan patut untuk dikaji lebih mendalam.

Terjadinya pergeseran wilayah dari desa ke kota menyebabkan wilayah pedesaan di Jawa menjadi lebih dinamis dibandingkan dengan wilayah perkotaan pada periode yang sama. Bahkan beberapa wilayah yang awalnya masuk dalam kategori pedesaan lambat laun berubah menjadi kota kecil akibat dari stimulus yang berlangsung selama masa eksploitasi pedesaan (Basundoro, 2009:3). Maka dari itu dapat dikatakan selanjutnya bahwa sejarah mengenai pedesaan lebih banyak dibahas daripada sejarah kota.

Penulisan sejarah saat itu masih tertuju pada sejarah pedesaan karena secara politis pedesaan dianggap lebih mewakili sebagian besar realitas sejarah Indonesia sejak masa kolonial. Kebijakan yang ada pada masa kolonial seperti tanam paksa dianggap lebih menguntungkan secara ekonomi dan kebijakan revolusi hijau yang menguntungkan secara politis. Sejarah kota pada saat itu lebih banyak ditulis oleh orang-orang Eropa yang datang atau bahkan bermukim di Indonesia (Basundoro, 2009).

Seiring dengan tumbuhnya kelas menengah dengan cepat di perkotaan, terdapat tuntutan 
fasilitas kota yang memadai cukup tinggi. Orang-orang Eropa menginginkan agar kotakota di Indonesia dibangun mirip dengan kotakota mereka di Eropa. Beberapa kota besar akhirnya tumbuh menjadi kota modern. Keterlibatan para pemodal swasta untuk menanamkan modalnya memiliki peran yang besar dalam modernisasi kota-kota besar di Indonesia. Bangunan-bangunan berskala besar dengan gaya arsitektur bergaya barat dibangun dan difungsikan untuk berbagai keperluan seperti keperluan bisnis, pemerintahan, agama, maupun hiburan (Basundoro, 2009). Perkembangan ini juga ditulis oleh orang-orang Eropa dengan gaya tulisan mereka sendiri.

Makkelo (2018) juga menjelaskan bahwa penulisan sejarah Indonesia lebih didominasi oleh penulisan sejarah politik, sejarah tokohtokoh besar dan juga berbagai warisan sejarah kerajaan masa lampau. Namun dalam beberapa kurun waktu terakhir terdapat perhatian akan penulisan sejarah kota baik dalam penulisan ditingkat perguruan tinggi maupun berbagai seminar terkait metode dan penelitian sejarah kota.

Oleh karena itu, di bawah ini akan dibahas mengenai sejarah kota yang terfokus dalam penjabaran konsep the new urban history dengan studi kasus perubahan monumen KNIP menjadi monumen Sarinah di Kota Malang. Penggunaan studi kasus dimaksudkan agar konsep the new urban history dalam sejarah kota dapat dipahami secara jelas. Selain itu penggunaan studi kasus juga digunakan dengan tujuan sedikit menjelaskan perkembangan modernisasi di salah satu sudut Kota Malang.

\section{METODE}

Penelitian ini menggunakan metode kualitatif. Penelitian dilakukan dengan studi pustaka dan wawancara. Pengumpulan data dengan studi pustaka dilakukan dengan mencari sumber buku dan melakukan riset ilmiah terhadap artikel yang relevan. Peneliti juga melakukan kritik terhadap sumber yang ada agar mendapatkan hasil yang lebih valid terutama artikel yang terbit di jurnaljurnal yang memiliki open acces. Kemudian dalam wawancara, narasumber yang dipilih merupakan orang yang ahli di bidangnya (Sugiyono, 2014). Narasumber yang dipilih adalah Bapak Dwi Cahyono yang merupakan Dosen Universitas Negeri Malang sekaligus sejarawan Malang. Hasil pembahasan yang ditulis berdasarkan sumber yang diyakini penulis sebagai sumber yang akurat dan kredibel.

\section{HASIL DAN PEMBAHASAN KONSEP THE NEW URBAN HISTORY}

Sejarah kota memiliki bidang kajian yang luas seperti halnya sejarah sosial. Sejarah kota dapat masuk ke berbagai bidang sejarah lain seperti sejarah lokal, ekonomi, politik dan lain sebagainya. Di berbagai bidang sejarah tersebut, kota menjadi lokasi berbagai kajian yang dibahas (Kuntowijoyo, 2003). Bila tidak terdapat pembatasan yang jelas maka akan terjadi campur aduk akan kajian dalam bidang sejarah. Hal ini jelas menimbulkan suatu ketidakjelasan suatu bidang kajian yang akan dikaji dikemudian hari.

Batasan kajian dalam sejarah kota penting untuk diperjelas. Terdapat dua pembagian mengenai hal ini. Proses perkembangan kota menjadi bagian dari sejarah kota, sedangkan hasil dari sejarah kota itu disebut the new urban history. Pembatasan ini bertujuan untuk 
mengembalikan bidang sejarah kota kepada gejala kekotaan yang khas. Pembatasan ini dimaksudkan juga untuk memperjelas dan mengukuhkan sejarah kota sebagai bagian dari penulisan sejarah (Kuntowijoyo, 2003).

Pembatasan ini memiliki berbagai inti permasalahan yang nantinya akan dibahas dalam sejarah kota. Pertama, bidang kajian sejarah kota adalah perkembangan ekologi kota. Ekologi menurut Utomo, Sutriyono, dan Rizal (2016) adalah ilmu yang mempelajari hubungan timbal balik antara makhluk hidup dengan lingkungannya. Apabila salah satu komponen dari ekologi terjadi perubahan maka komponen lainnya juga akan berubah. Maka dari itu perkembangan ekologi kota dapat dikatakan sebagai perkembangan masyarakat dengan kota. Perkembangan ekologi kota dimulai dengan perkembangan pola pemukiman, terdapat perbedaan yang cukup signifikan dalam hal ini $\mathrm{Di}$ kota tradisional pola pembagian pemukiman didasarkan pada etnis dan status. Hal ini akibat dari politik pemukiman masa lalu. Di kota modern pola pembagian pemukiman didasarkan pada kelas sosial. Adanya kampungkampung di kota juga disebabkan oleh perubahan pola pemukiman berdasarkan kelas tersebut (Kuntowijoyo, 2003).

Setelah adanya perkembangan pola pemukiman, terdapat perubahan pada kondisi lingkungan, misalnya secara sosiologis maupun psikologis. Dalam ranah sosiologis, lingkungan elite kota menunjukkan dengan jelas simbol dominasi terhadap kelas bawah, hal ini secara langsung melahirkan ketimpangan sosial. (Kuntowijoyo, 2003). Dapat kita lihat hingga saat ini lingkungan elite masih bertahan dan menjadi simbol perbedaan kelas juga. Kondisi ini merupakan suatu bagian dari perkembangan kota yang tidak dapat dipisahkan.

Perkembangan ekologi kota juga terjadi akibat adanya kemajuan teknologi. Teknologi yang memadai menghasilkan jalan, jembatan, bangunan, saluran air, dan pembangunan perumahan (Kuntowijoyo, 2003). Hal ini membuat lingkungan kota berubah seiring perkembangan zaman. Kota-kota modern terus berkembang mengikuti tren yang berlangsung. Kemajuan bidang transportasi juga merupakan penyebab berkembangnya ekologi kota. Pendirian-pendirian industri juga menyusul akibat dari majunya alat transportasi. Akibat langsung lainnya adalah adanya perubahan pola tukar menukar ekonomi yang tampak dalam bangunan fisik di kota seperti departement store. Selain itu berkembangnya birokrasi perbankan dan sekolah juga mempengaruhi perubahan ekologi kota.

Kedua, bidang sejarah kota selanjutnya adalah transformasi sosial ekonomis. Pergeseran pola pedesaan ke perkotaan dengan urbanisasi merupakan bagian dari perubahan sosial. Urbanisasi menurut Haris (2015) terjadi akibat adanya proses perubahan atau pertumbuhan suatu kota. Maka dari itu urbanisasi dapat disebut sebagai suatu proses perpindahan penduduk dari desa ke kota. Perubahan ini diawali dengan munculnya kota tradisional dan kemudian diikuti oleh kota modern. Terdapat perbedaan tatanan dalam kedua kota tersebut.

Kota tradisional yang dimaksud disini adalah keraton dan lingkungan kota-negara secara sosial, ekonomis, dan kultural memisahkan diri 
dengan desa. Wilayah tersebut merupakan pusat kerajaan yang memiliki aturan-aturan tersendiri berbeda dengan masyarakat desa. Kota tradisional memiliki sistem status yang ketat, hal ini akibat dari dekatnya masyarakat dengan raja sehingga pengaruh kesaktian raja sangat terasa (Kutoyo, 1978). Berbagai aturan yang keras diterapkan ketika seseorang berada di sekitar istana. Aturan tersebut menunjukkan status masing-masing dalam tatanan kerajaan. Di dalam kota tradisional terdapat simbol-simbol kekuasaan raja yang diwujudkan dalam berbagai bangunan fisik, upacara dan hak-hak istimewa. Kraton juga merupakan wujud dari birokrasi tradisional dimana dapat mengatur kekuasaan ekonomi dan sosial, serta tempat surplus produksi yang dibagikan kepada pembantu-pembantu raja (Kuntowijoyo, 2003).

Tatanan dalam kota modern juga berbeda dengan kota tradisional. Di dalam kota modern pembagian penduduk didasarkan pada kelas sosial dengan mobilitas sosial yang tidak ketat seperti sebelumnya. Beberapa pola yang diterapkan dalam kota modern adalah penggunaan mesin dalam produksi barangbarang secara massal dengan pelayanan dan kualitas yang baik; organisasi produksi dipegang oleh unit-unit ekonomi yang cenderung besar dengan standarisasi dalam harga, timbangan, dan takaran; dan adanya birokrasi yang diangkat secara rasional. Di Indonesia sejak awal abad ke-20 telah ada golongan pengusaha di kota yang menjadi penggerak bagi kemajuan sosial-ekonomi kota (Kuntowijoyo, 2003).

Ketiga, bidang sejarah kota selanjutnya adalah sistem sosial. Kegiatan masyarakat kota dapat dijadikan sebagai bahan kajian seperti kegiatan domestik, agama, rekreasi, ekonomis, politis, kultural, dan hubungan antar warga secara struktural antara lembaga-lembaga masyarakat, hubungan kategorikal antara kelompok-kelompok etnis, status dan kelas, dan bahkan hubungan personal antara ssesama warga kota. Ketika mengkaji sistem sosial dapat menggunakan sumber selain bahan-bahan dokumenter seperti berbagai tulisan yang sudah di terbitkan seperti majalah, surat kabar dan buku-buku sastra untuk mengetahui gambaran mengenai kota. Perkembangan sistem sosial juga dapat digali melalui sumber lisan. Masih banyak bagian dari sistem sosial sejak awal abad ke-20 belum dikaji, maka kemungkinan terdapat sumber lisan yang memadai (Kuntowijoyo, 2003). Perkembangan sistem sosial suatu kota tradisional dapat dipahami melalui interaksi masyarakat berbagai komunitas adat yang berkuasa saat itu. Saat ini perubahan sistem sosial suatu kota dapat dipahami melalui dominasi lembaga dagang yang mempunyai skala menengah keatas. Perkembangan ini juga menjadi bagian dari sejarah kota (Handoyo, Tri Astuti, Iswari, Alimi, \& Mustofa, 2015).

Keempat, bidang sejarah kota selanjutnya adalah problem sosial. Pengkajian perkembangan ekologi, transformasi sosial dan sistem sosial memiliki dampak masalah masingmasing. Perkembangan ekologi memiiki dampak pada masalah kepadatan penduduk, mobilitas horisontal dan heterogenitas. Masalah-masalah yang ditimbulkan yaitu disparitas dan pemisahan pemukiman secara ekonomi dan sosial, ketimpangan demografis, dan masalah lingkungan baik fisik, sosial, dan psikologis. Adanya kampung-kampung dengan standar lingkungan yang rendah dapat menjadi masalah 
sosial yang timbul dari lingkungan kota. masalah ekologis lainnya dapat berupa masalah pembuangan air, sampah dan kepadatan lalu lintas (Kuntowijoyo, 2003). Masalah-masalah tersebut dialami olah masyarakat perkotaan seiring dengan perkembangan kota yang semakin maju. Masalah-masalah tersebut dapat menjadi bidang kajian sejarah.

Dampak dari transformasi sosial juga menyebabkan masalah-masalah sosial yang menarik untuk dikaji. Pergeseran antara kelaskelas sosial dalam masyarakat merupakan salah satu masalah akibat adanya transformasi sosial. Masalah tersebut berupa adanya kasus kejahatan sosial, tindakan kekerasan dan kerusuhan di berbagai kota serta perkelahian antara kelompok-kelompok bawah. Masalah lain seperti prostitusi, pengangguran dan pengedaran obat-obat terlarang yang jarang sekali dibahas oleh para sejarawan (Kuntowijoyo, 2003). Masalah-masalah yang timbul dari transformasi sosial saat ini sudah mulai dikaji oleh para sejarawan. Di berbagai kalangan akademisi, masalah tersebut juga mendapat perhatian khusus. Hal ini dilakukan dengan tujuan untuk mempelajari sejarah melalui sisi yang lain.

Sistem sosial yang ada dalam masyarakat juga tak luput membawa dampak masalah. Salah satu masalah yang timbul yaitu adanya boss di setiap kota yang memiliki berbagai tugas seperti menjadi tulang punggung bagi sistem kepartaian di suatu kota, pelopor pembangunan kota, pemberi pelindung dari suatu tindakan korupsi atau kejahatan yang terorganisir. Di Indonesia hal tersebut sangat sulit untuk dibahas karena bersifat rahasia (Kuntowijoyo,
2003). Ketika berkas-berkas pendukung dan berbagai kesaksian dapat terbuka maka masalah tersebut dapat ditulis dan menjadi kajian menarik di kalangan sejarawan.

Kelima, bidang sejarah kota selanjutnya adalah mobilitas sosial. Mobilitas sosial dapat dikaji secara kuantitatif. Catatan kuantitatif memang tidak mudah didapatkan yang terkait dengan perkembangan kelas sosial di kota (Kuntowijoyo, 2003). Semakin majunya perkembangan zaman, data-data kuantitatif dari perkembangan kelas sosial mulai banyak diolah menjadi kajian-kajian sejarah. Dalam bidang ekonomi misalnya perkembangan pedagang kecil hingga menengah mulai diperhitungkan perannya dalam meningkatkan kualitas ekonomi dari suatu kota. Mobilitas sosial juga dapat disesuaikan dengan konteks yang ada seperti pekerjaan masyarakat kota, peningkatan upah pekerja di kota industri dan lain sebagainya (Wijayati, 2019).

Dari berbagai proses yang menjadi batasan di atas menjadi hasil dari sejarah kota. Hasil sejarah kota tersebut disebut the new urban history. Salah satu hasil sejarah kota adalah dibangunnya berbagai monumen atau penanda dari perkembangan ekologi, lingkungan sosial, sistem sosial, problem sosial hingga mobilitas sosial suatu kota.

\section{PERUBAHAN MONUMEN KNIP KE MONUMEN SARINAH DI KOTA MALANG}

Perubahan fisik dari suatu kota lambat laun semakin kompleks. Pemanfaatan tata ruang kota untuk berbagai kepantingan mulai benarbenar diatur. Alih fungsi dan alih bentuk suatu bangunan dari zaman ke zaman juga 
Putri, 2021, Konsep The New Urban History. . .

merupakan hal yang tak bisa terhindarkan. Hal ini karena arus perkembangan zaman yang semakin maju. Pembuatan beberapa simbol kota sebagai sarana pengingat akan sejarah kota menjadi hal yang pentig dalam tata kelola kota saat ini. Monumen KNIP (Komite Nasional Indonesia Pusat) adalah salah satu wujud penting dalam sejarah Kota Malang. Namun seiring perkembangan zaman, monumen tersebut hilang tak berbekas. Maka dari itu perlu ditelusuri perjalanan monumen tersebut agar untuk ke depannya tidak terjadi hal serupa.

Monumen ini diresmikan pada bulan Mei 1992. Monumen ini berfungsi untuk mengingatkan bahwa di tempat tersebut pada tahun 1947 berlangsung sidang pertama Parlemen Republik Indonesia. Sidang itu berlangsung di Gedung Societeit Concordia dan diliput oleh Pers Asing. Tercatat semenjak dibentuknya parlemen pertama yang bernama PPKI (Panitia Persiapan Kemerdekaan Indonesia). PPKI setelah itu menjadi KNIP (Komite Nasional Indonesia Pusat) dan tidak pernah bersidang sejak 18 Agustus 1945. Prasasti di monumen ini bertuliskan "Di tempat ini pada tanggal 25 Februari hingga 5 Maret 1947 para anggota KNIP memancangkan Tonggak Persatuan untuk berjuang menegakkan kemerdekaan kebangsaan berdasarkan Pancasila dan UUD 1945" (Hudiyanto, 2014).

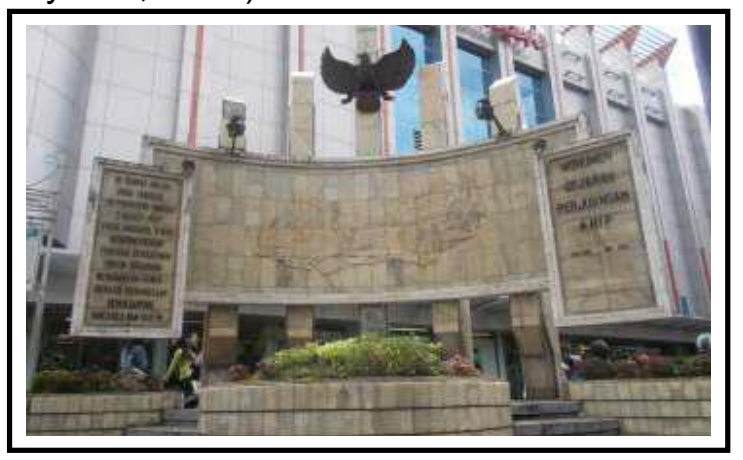

Gambar 1. Monumen KNIP

(Sumber : Hudiyanto, 2014:37)

Hudiyanto (2014) menyatakan bahwa dalam Monumen KNIP ini memiliki karakter yang berbeda dengan monumen lain, tidak ada tokoh yang ditonjolkan dalam relief dan monumen ini. Figur yang terdapat pada relief hanya gambaran suasana sidang. Berbeda dengan monumen tugu Kota Malang yang menampilkan figur Soekarno-Hatta, pada monumen KNIP figur kedua tokoh tersebut tidak terlihat. Disamping itu, posisi monumen yang berada di depan Swalayan Sarinah seperti tidak nampak karena tidak berada di lokasi strategis. Monumen ini berada di sideway sehingga jika ada orang melintas akan kesulitan melihatnya. Pengendara lebih tertarik melihat papan iklan rokok yang dipasang di pinggir jalan Merdeka Utara. Maka dari itu, monumen ini kehilangan daya tarik yang disebabkan oleh banyaknya papan advertensi di sekelilingnya.

Mulai tahun 1992 sejak Monumen KNIP didirikan, 24 tahun kemudian monumen tersebut dibongkar terutama setelah adanya renovasi Gedung Sarinah yang baru. Untuk beberapa lama monumen tetep ada setelah renovasi Gedung Sarinah yang terbaru. Alasan dibalik dirobohkannya Monumen KNIP dikarenakan menurut pihak Sarinah monumen ini dianggap sebagai penghalang view, Sarinah dibangun dengan view di pojok dan tower Sarinah tertutup monumen, nyatanya ukuran monumen tidak setinggi tower yang ada di belakangnya (Hartik, 2016). Tetapi tetap saja adanya monumen ini dianggap sebagai batu sandungan untuk kepopuleran Sarinah sendiri. Karena monumen KNIP sarat akan nilai sejarah dan dengan dirobohkannya monumen tersebut pada tahun 
2016 secara tidak langsung melahirkan kritik tegas dari berbagai pihak (Cahyono, 2021).

Masalah tersebut pada akhirnya menimbulkan polemik yang berkepanjangan. Setelah itu dibangun monumen yang baru berupa monumen rangkaian huruf membentuk kata Sarinah yang kemudian dikenal sebagai Monumen Sarinah. Sama-sama sebagai petanda tetapi terdapat perbedaan diantara keduanya. Dulu monumen yang ada menjadi petanda untuk Societeit Concordia dan tempat kongres KNIP, kemudian di masa sekarang monumen yang ada merupakan penanda bidang usaha yaitu Sarinah. Subyektivitas Sarinah yang dikedepankan karena jelas-jelas tidak memikirkan bagaimana pengaruh dari Monumen KNIP. Banyak reaksi keras yang tumbuh, salah satunya dari pihak TACB (Tim Ahli Cagar Budaya) Kota Malang yang melayangkan protes tetapi hal itu percuma karena wujud atau bentuk dari Monumen KNIP sudah hilang (Widianto, 2016). Menurut keterangan Pihak Sarinah bagian marmer yang ada tulisannya disimpan di gudangnya, tetapi kalaupun disimpan juga tidak ada manfaatnya. Bahkan logikanya untuk bentuknya masih tetap terjaga dan terawat itu masih menjadi bahan pertanyaan (Cahyono, 2021).

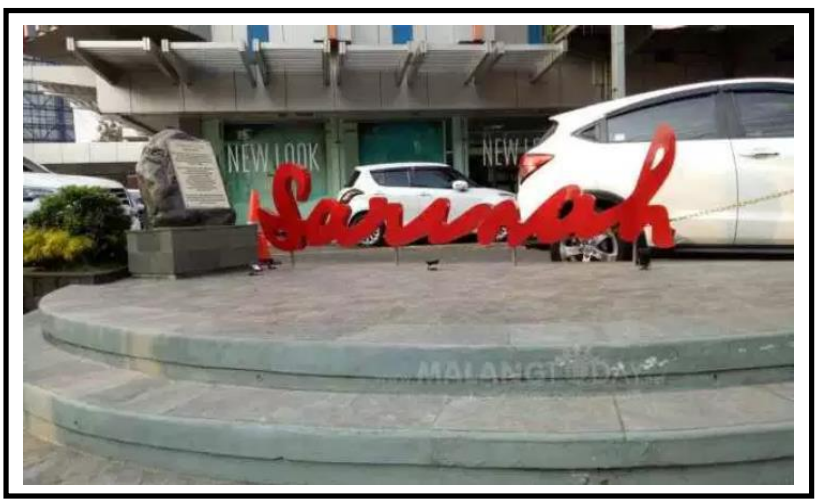

Gambar 2. Monumen Sarinah (Sumber : http://malangtoday.net)
Ini sangat disayangkan karena Monumen KNIP yang penuh akan nilai sejarah sebagai petanda Gedung Societeit Concordia dibongkar. Ketika mendapat protes itu Pihak Sarinah menyadari akan kesalahannya. Dulu Pihak Sarinah ingin membuat sesuatu petanda ditempelkan di tempat berbeda, tetapi jelas ini akan berbeda dengan posisi semula yang berada dipojok karena tidak akan dilihat orang. Disatu sisi terdapat gerakan kedasaran untuk memunculkan petanda terhadap bangunan yang telah lama hilang. Disisi lain muncul ketidakpedulian terhadap gedung yang ada, ironinya justru yang melakukan ini adalah BUMN bukan murni swasta itu yang disayangkan (Cahyono, 2021).

Di dekat Monumen Sarinah ternyata dibuat batu kecil oleh Pihak Sarinah. Di dalam batu tersebut terukir tulisan yang isinya hampir sama dengan yang ada di Monumen KNIP dahulu. Bentuk dari batu tersebuh tidak menonjol cenderung lebih kecil dari tulisan Sarinah yang ada di sampingnya. Batu kecil tersebut digunakan sebagai bahan pembelaan oleh pihak Sarinah bahwa mereka tidak menghilangkan sama sekali petanda untuk Gedung eks Societeit Concordia. Batu kecil tersebut dibuat untuk sekedar ada dan posisi batu mengarah ke dalam Sarinah tidak ke arah jalan, sudah jelas bahwa batu kecil tersebut tidak akan bisa menggantikan Monumen KNIP yang terdahulu. Pihak Sarinah mangatakan menyesal akan penggantian Monumen KNIP menjadi Monumen Sarinah tetapi dengan adanya batu kecil sebagai penebusan, Monumen KNIP tetap tidak bisa diwujudkan kembali (Cahyono, 2021). 
Putri, 2021, Konsep The New Urban History. . .

IMPLEMENTASI KONSEP THE NEW URBAN HISTORY DALAM STUDI KASUS PERUBAHAN MONUMEN KNIP KE MONUMEN SARINAH DI KOTA MALANG

Perubahan Monumen KNIP ke Monumen Sarinah di Kota Malang memiliki berbagai hal yang melatar-belakanginya. Hingga saat ini belum ada penjelasan yang jelas mengenai apa penyebab diubahnya monumen tersebut. Namun berdasarkan apa yang diamati alasan dibalik diubahnya Monumen KNIP menjadi Monumen Sarinah dikarenakan menurut pihak Sarinah, monumen ini dianggap sebagai penghalang view. Sarinah dibangun dengan view di pojok dan tower Sarinah tertutup monumen, nyatanya ukuran monumen tidak setinggi tower yang ada di belakangnya. Tetapi tetap saja adanya monumen ini dianggap sebagai batu sandungan untuk kepopuleran Sarinah sendiri.

Sebelum membahas mengenai perubahan monumennya dipandang dari konsep the new urban history sebagai hasil sejarah kota, perlu dipahami pembangunan Pusat Perbelanjaan Sarinah juga menjadi bagian dari proses sejarah kota sebelum adanya Monumen KNIP. Hal ini dapat dilihat sebagai dampak dari perkembangan ekologi kota dan lingkungan sosial ekonomis. Leempt dan Cahyono dalam Suprapta (2016) menjelaskan bahwa Pusat Perbelanjaan Sarinah dibangun di atas tanah yang dahulunya berdiri gedung Societeit Concordia. Gedung Societeit Concordia pernah menjadi tempat Sidang KNIP di tahun 1947. Tahun 1948 gedung ini dihancurkan oleh para pejuang kemerdekaan demi mencegah dimanfaatkan kembali oleh Belanda. Tidak diketahui tepatnya pada tahun berapa, setalah kejadian penghancuran tersebut, gedung diratakan dengan tanah dan dibangun Pusat Perbelanjaan Sarinah.

Tidak ada tulisan khusus yang dapat dipertanggungjawabkan mengenai pembagunan Pusat Perbelanjaan Sarinah di Kota Malang. Akan tetapi berdasarkan teori perkembangan ekologi kota dapat dikatakan bahwa pembangunan Pusat Perbelanjaan Sarinah adalah wujud dari perkembangan ekologi kota. Letak lahan yang dibangun ini sangat strategis yakni berada di pusat Kota Malang, tepatnya berada di sebelah utara Alun-Alun Malang. Pembangunan kawasan Alun-Alun Malang yang semakin modern tak luput juga mempengaruhi dibangunnya pusat perbelanjaan di sekelilingnya. Dibangunnya pusat perbelanjaan ini merupakan ciri khas kota modern. Pola transaksi ekonomi yang semakin berkembang juga menjadi alasan banyak berdirinya pusat perbelanjaan.

Pembangunan pusat perbelanjaan Sarinah juga merupakan dampak dari adanya perkembangan lingkungan sosial ekonomis. Hal ini dapat dikatakan demikian karena saat itu pertumbuhan Kota Malang lambat laun menjadi kota modern yang semakin maju. Banyak pengusaha yang tertarik untuk ikut andil dalam pembangunan sosial ekonomi kota, tak terlepas dengan pembangunan pusat perbelanjaan. Kawasan yang strategis dan mulai berubahnya pola ekonomi manusia membuat Pusat Perbelanjaan Sarinah tumbuh di Malang, bahkan juga di kota-kota besar lainnya.

Ketika Pusat Perbelanjaan Sarinah berkembang dibangunlah Monumen KNIP. Monumen KNIP dapat dikatakan sebagai hasil 
dari sejarah kota atau the new urban history. Hal ini dikarenakan begitu pentingnya gedung Societeit Concordia dalam sejarah Kota Malang, bahkan sejarah nasional. Sehingga, saat gedung tersebut sudah dibangun kembali dengan fungsi yang berbeda jauh maka adanya Monumen KNIP dianggap sangat penting sebagai pengingat peristiwa yang telah terjadi sebelumnya.

Pada tahun 2016, Monumen KNIP diruntuhkan dan diganti menjadi Monumen Sarinah. Hal ini juga daoat dipandang sebagai hasil dari sejarah kota atau the new urban history. Perkembangan Kota Malang yang semakin maju dan daya saing dalam hal ekonomi yang semakin tinggi membuat pihak terkait mengubah Monumen KNIP menjadi Monumen Sarinah. Pembangunan Monumen Sarinah mungkin dapat menjadi daya tarik dan minat pengunjung untuk datang ke Pusat Perbelanjaan Sarinah. Sebelumnya Monumen KNIP dianggap menutupi pandangan masyarakat akan Pusat Perbelanjaan Sarinah.

Perubahan monumen ini menjadi salah satu tanda bahwa perkembangan sejarah kota terjadi sangat menarik. Apapun bisa terjadi seiring dengan majunya zaman. Bila tidak ada pembahasan mengenai sejarah kota, maka di kemudian hari kita tidak akan dapat mengenang akan betapa indahnya kota-kota zaman dulu dengan berbagai perkembangannya yang tidak dapat kita temukan sekarang seperti gedung Societeit Concordia yang sudah hilang bahkan penandanya pun sudah digantikan (Rully Damayanti \& Handinoto, 2005).

\section{KESIMPULAN}

Sejarah kota memiliki bidang kajian yang luas seperti halnya sejarah sosial. Sejarah kota dapat masuk ke berbagai bidang sejarah lain seperti sejarah lokal, ekonomi, politik dan lain sebagainya. Batasan kajian dalam sejarah kota penting untuk diperjelas. Terdapat dua pembagian mengenai hal ini. Proses perkembangan kota menjadi bagian dari sejarah kota, sedangkan hasil dari sejarah kota itu disebut the new urban history. Pembatasan ini memiliki berbagai inti permasalahan yang nantinya akan dibahas dalam sejarah kota. Bidang kajian sejarah kota adalah perkembangan ekologi kota, transformasi sosial ekonomis, sistem sosial, problem sosial dan mobilitas sosial. Dari berbagai proses yang menjadi batasan di atas menjadi hasil dari sejarah kota. Hasil sejarah kota tersebut disebut the new urban history. Salah satu hasil sejarah kota adalah dibangunnya berbagai monumen atau penanda dari perkembangan ekologi, lingkungan sosial, sistem sosial, problem sosial hingga mobilitas sosial suatu kota.

Monumen KNIP diresmikan pada bulan Mei 1992. Monumen ini berfungsi untuk mengingatkan bahwa di tempat tersebut pada tahun 1947 berlangsung Sidang Pertama Parlemen Republik Indonesia. Sidang itu berlangsung di Gedung Societeit Concordia dan diliput oleh Pers Asing. Sejak Monumen KNIP didirikan, 24 tahun kemudian monumen tersebut dihilangkan terutama setelah adanya renovasi Gedung Sarinah yang baru. Untuk beberapa lama monumen tetep ada setelah renovasi Gedung Sarinah yang terbaru. Tak lama diganti dengan Monumen Sarinah. Di dekat Monumen 
Putri, 2021, Konsep The New Urban History. . .

Sarinah ternyata dibuat batu kecil oleh Pihak Sarinah. Batu kecil tersebut digunakan sebagai bahan pembelaan oleh Pihak Sarinah bahwa mereka tidak menghilangkan sama sekali petanda untuk Gedung eks Societeit Concordia. Sudah jelas bahwa batu kecil tersebut tidak akan bisa menggantikan Monumen KNIP yang terdahulu. Pihak Sarinah mangatakan menyesal akan penggantian Monumen KNIP menjadi Monumen Sarinah tetapi dengan adanya batu kecil sebagai penebusan, Monumen KNIP tetap tidak bisa diwujudkan kembali.

Sebelum membahas mengenai perubahan monumennya dipandang dari konsep the new urban history sebagai hasil sejarah kota, perlu dipahami pembangunan Pusat Perbelanjaan Sarinah juga menjadi bagian dari proses sejarah kota sebelum adanya Monumen KNIP. Pembangunan Pusat Perbelanjaan Sarinah adalah wujud dari perkembangan ekologi kota. Letak lahan yang dibangun ini sangat strategis yakni berada di pusat Kota Malang, tepatnya berada di sebelah utara Alun-Alun Malang. Pembangunan kawasan Alun-Alun Malang yang semakin modern tak luput juga mempengaruhi dibangunnya pusat perbelanjaan di sekelilingnya. Dibangunnya pusat perbelanjaan ini merupakan ciri khas kota modern. Pola transaksi ekonomi yang semakin berkembang juga menjadi alasan banyak berdirinya pusat perbelanjaan. Pembangunan Pusat Perbelanjaan Sarinah juga merupakan dampak dari adanya perkembangan lingkungan sosial ekonomis. Hal ini dapat dikatakan demikian karena saat itu pertumbuhan Kota Malang lambat laun menjadi kota modern yang semakin maju. Banyak pengusaha yang tertarik untuk ikut andil dalam pembangunan sosial ekonomi kota, tak terlepas dengan pembangunan pusat perbelanjaan.

Monumen KNIP dapat dikatakan sebagai hasil dari sejarah kota atau the new urban history. Hal ini dikarenakan begitu pentingnya gedung Societeit Concordia dalam sejarah Kota Malang, bahkan sejarah nasional. Sehingga, saat gedung tersebut sudah dibangun kembali dengan fungsi yang berbeda jauh maka adanya Monumen KNIP dianggap sangat penting sebagai pengingat peristiwa yang telah terjadi sebelumnya. Pada tahun 2016, Monumen KNIP diruntuhkan dan diganti menjadi Monumen Sarinah. Hal ini juga dapat dipandang sebagai hasil dari sejarah kota atau the new urban history. Perkembangan Kota Malang yang semakin maju dan daya saing dalam hal ekonomi yang semakin tinggi membuat pihak terkait mengubah Monumen KNIP menjadi Monumen Sarinah. Pembangunan Monumen Sarinah mungkin dapat menjadi daya tarik dan minat pengunjung untuk datang ke Pusat Perbelanjaan Sarinah. Sebelumnya Monumen KNIP dianggap menutupi pandangan masyarakat akan Pusat Perbelanjaan Sarinah. Perubahan monumen ini menjadi salah satu tanda bahwa perkembangan sejarah kota terjadi sangat menarik. Apapun bisa terjadi seiring dengan majunya zaman. Bila tidak ada pembahasan mengenai sejarah kota, maka di kemudian hari kita tidak akan dapat mengenang akan betapa indahnya kota-kota zaman dulu dengan berbagai perkembangannya yang tidak dapat kita temukan sekarang seperti gedung Societeit Concordia yang sudah hilang bahkan penandanya pun sudah digantikan. 


\section{DAFTAR PUSTAKA}

Basundoro, P. (2009). Dua Kota Tiga Zaman: Surabaya dan Malang Sejak Zaman Kolonial sampai Kemerdekaan. Yogyakarta: Ombak.

Cahyono, M. D. (2021). Wawancara ahli. Malang.

Handoyo, E., Tri Astuti, M. P., Iswari, R., Alimi, Y., \& Mustofa, M. S. (2015). Studi Masyarakat Indonesia. Yogyakarta: Ombak.

Haris, A. (2015). Studi Media Dan Perpustakaan Tentang Urbanisasi. J. Jupiter, XIV(1), 6065.

Hartik, A. (2016). Monumen Sejarah KNIP Dibongkar Jadi Batu dan Logo Sarinah. Retrieved July 24, 2021, from Kompas.com website:

https://regional.kompas.com/read/2016/08/ 02/15160371/monumen.sejarah.knip.dibon gkar.jadi.batu.dan.logo.sarinah

Hudiyanto, R. R. (2014). Konstruksi Politik Negara Melalui Tradisi Penamaan Jalan dan Penempatan Patung di Kota Malang: Kajian Urban Simbol dalam Rekronstruksi Perkembangan Kota (Universitas Negeri Malang). Universitas Negeri Malang. Retrieved from https://docplayer.info/94282545-Blufakultas-ilmu-sosial-universitas-negerimalang.html

Kuntowijoyo. (2003). Metodologi Sejarah (Kedua). Yogyakarta: Tiara Wacana Yogya.

Kutoyo, S. (1978). Sejarah Kebangkitan Nasional Daerah Bengkulu. Bengkulu: P3KD.

Makkelo, I. D. (2018). Sejarah Perkotaan: Sebuah Tinjauan Historiografis dan Tematis. Lensa Budaya: Jurnal IImiah IImuIlmu Budaya, 12(2), 83-101. https://doi.org/10.34050/JLB.V12I2.3052

Rully Damayanti, \& Handinoto. (2005). Kawasan "Pusat Kota" dalam Perkembangan Sejarah Perkotaan di Jawa. DIMENSI (Jurnal Teknik Arsitektur), 33(1), 34-42. Retrieved from

http://puslit2.petra.ac.id/ejournal/index.php/ ars/article/view/16274

Sugiyono. (2014). Metode Penelitian Kuantitatif, Kualitatif, dan $R \& D$. Bandung: Alfabeta.
Suprapta, B. (2016). Model Pemanfaatan Cagar Budaya Untuk. Sejarah Dan Budaya, 10(1), 11-30.

Utomo, S. W., Sutriyono, \& Rizal, R. (2016). Pengertian, Ruang Lingkup Ekologi dan Ekosistem. In Modul 1 (pp. 1-31). Jakarta: Universitas Terbuka. Retrieved from http://repository.ut.ac.id/4305/

Widianto, E. (2016). Sejarawan Protes Pembongkaran Monumen KNIP di Malang.

Wijayati, P. A. (2019). Semarang dan Surabaya dalam Perspektif Historis dan Ekonomi Kota: Sebuah Pemikiran Historiografis. SASDAYA: Gadjah Mada Journal of Humanities, 2(1), 334. https://doi.org/10.22146/sasdayajournal.31 747 